University of Wollongong

Research Online

Australian Institute for Innovative Materials -

Papers

Australian Institute for Innovative Materials

$1-1-2016$

\title{
A methodical approach for fabrication of binder-free Li2S-C composite cathode with high loading of active material for Li-S battery
}

Mohammad Kaiser

University of Wollongong, mrk912@uowmail.edu.au

Xin Liang

University of Wollongong, x|475@uowmail.edu.au

Hua-Kun Liu

University of Wollongong, hua@uow.edu.au

SX. Dou

University of Wollongong, shi@uow.edu.au

Jiazhao Wang

University of Wollongong, jiazhao@uow.edu.au

Follow this and additional works at: https://ro.uow.edu.au/aiimpapers

Part of the Engineering Commons, and the Physical Sciences and Mathematics Commons

Research Online is the open access institutional repository for the University of Wollongong. For further information contact the UOW Library: research-pubs@uow.edu.au 


\title{
A methodical approach for fabrication of binder-free Li2S-C composite cathode with high loading of active material for Li-S battery
}

\begin{abstract}
Lithium sulfide (Li2S), which has a theoretical capacity of $1166 \mathrm{~mA} \mathrm{~h} / \mathrm{g}$, is considered as a promising cathode material for the Li-S battery. The electrochemical performance of microsized Li2S is impaired, however, by its low electrical conductivity as well as first cycle high activation potential problem. In this work, microsized Li2S powder had been ball-milled with different carbon sources to synthesize Li2S-C composites as well as to find the suitable carbon sources, which were then capillary-deposited in threedimensional multi-layered $\mathrm{Ni}$ foam from a dioxolane-containing mixture to fabricate a binder-free Li2S-C composite cathode. A large amount of active material $(\sim 5 \mathrm{mg} / \mathrm{cm} 2)$ was loaded in each cathode with the help of conventional capillary deposition method. Scanning electron micrographs show that the Li2S-C composite successfully fills the pores in the Ni foam through capillary action and maintains the integrity of the structure before and after cycling performance. Electrochemical performance testing shows that the capillary-deposited binder-free Li2S-C composite showed excellent cycling performance along with superior rate capability. For further improvement of electrochemical performance, a single-walled carbon nanotube free-standing layer was inserted in between the cathode and the separator which minimized polysulfides shuttle phenomenon thus improved the discharge capacity and the capacity retention.
\end{abstract}

\section{Keywords}

active, material, li, battery, loading, high, cathode, composite, c, approach, li2s, methodical, free, binder, fabrication

Disciplines

Engineering | Physical Sciences and Mathematics

\section{Publication Details}

Kaiser, M. Rejaul., Liang, X., Liu, H., Dou, S. \& Wang, J. (2016). A methodical approach for fabrication of binder-free Li2S-C composite cathode with high loading of active material for Li-S battery. Carbon, 103 163-171. 


\section{A Methodical approach for Fabrication of Binder-free $\mathrm{Li}_{2} \mathrm{~S}-\mathrm{C}$ composite Cathode with High Loading of Active Material for Li-S Battery}

Mohammad Rejaul Kaiser ${ }^{a}$, Xin Liang ${ }^{a}$, Hua-Kun Liu ${ }^{a}$, Shi-Xue Dou ${ }^{a}$, and Jia-zhaoWang ${ }^{\text {a,* }}$

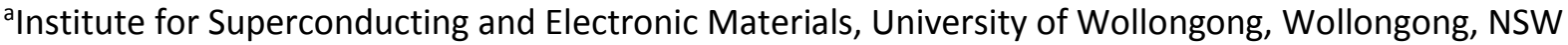
2522, Australia

*Corresponding author:

Tel: +61 24298 1478; Fax: +61 24221 5731;

E-mail address: jiazhao@uow.edu.au 


\section{Abstract}

Lithium sulfide $\left(\mathrm{Li}_{2} \mathrm{~S}\right)$, which has a theoretical capacity of $1166 \mathrm{mAh} / \mathrm{g}$, is considered as a promising cathode material for the Li-S battery. The electrochemical performance of microsized $\mathrm{Li}_{2} \mathrm{~S}$ is impaired, however, by its low electrical conductivity as well as first cycle high activation potential problem. In this work, microsized $\mathrm{Li}_{2} \mathrm{~S}$ powder had been ball-milled with different carbon sources to synthesize $\mathrm{Li}_{2} \mathrm{~S}-\mathrm{C}$ composites as well as to find the suitable carbon sources, which were then capillary-deposited in three-dimensional multi-layered $\mathrm{Ni}$ foam from a dioxolane-containing mixture to fabricate a binder-free $\mathrm{Li}_{2} \mathrm{~S}-\mathrm{C}$ composite cathode. A large amount of active material $\left(\sim 5 \mathrm{mg} / \mathrm{cm}^{2}\right)$ was loaded in each cathode with the help of conventional capillary deposition method. Scanning electron micrographs show that the $\mathrm{Li}_{2} \mathrm{~S}-\mathrm{C}$ composite successfully fills the pores in the $\mathrm{Ni}$ foam through capillary action and maintains the integrity of the structure before and after cycling performance. Electrochemical performance testing shows that the capillary-deposited binder-free $\mathrm{Li}_{2} \mathrm{~S}-\mathrm{C}$ composite showed excellent cycling performance along with superior rate capability. For further improvement of electrochemical performance, a single-walled carbon nanotube freestanding layer was inserted in between the cathode and the separator which minimized polysulfides shuttle phenomenon thus improved the discharge capacity and the capacity retention.

\section{Introduction}


It is now a great challenge to the scientific committee to improve the capacity of existing energy storage devices due to the advent of new electronic devices, electric cars, and hybrid electric vehicles. Commercially available rechargeable batteries show specific energy of $400 \mathrm{Wh} \mathrm{kg}^{-1}$ which is almost to their theoretical limit but still falls far short of expectations for high energy applications [1, 2]. It seems impossible to increase the specific energy of these existing batteries due to the inherent capacity limitations of the materials. Therefore, it is necessary to introduce new materials for high energy battery applications.

Among all the promising rechargeable batteries, the Li/S system is considered a strong candidate to replace the currently available commercial batteries, due to its availability, low cost, and high performance. The poor electrical conductivity of sulfur, however, the dissolution of long chain polysulfides into electrolyte, and the expansion in volume during the sulfur to sulfide transformation are the limiting factors for sulfur-based battery systems [3]. Extensive research has been conducted to reduce the impact of these problems by applying different techniques to load sulfur onto carbon materials [4-9]. Engineered sulfur-based cathode materials [10-12], as well as different electrolytes, binders $[13,14]$, and additives [15-19], are also being meticulously studied to solve these problems, but yet to be successful. Moreover, in the Li/S system, it is necessary to achieve full lithiation of the sulfur during discharging to achieve higher discharge capacity. Unfortunately, this is unlikely to happen with elemental sulfur-based cathode, which negatively affects the performance of the Li/S cell. On top of that, the metallic lithium that has been used as anode for the Li/S system forms dendritic structures during operation, which penetrate through the separator and can cause short circuits and fire. Besides this major safety concern, metallic lithium is highly reactive, so it reacts with the electrolyte and degrades the cell performance. Considering all the shortcomings of elemental sulfur-based cathode, the performance and the safety concerns for the Li/S battery can be ameliorated by using prelithiated cathode, which helps to avoid the direct use of metallic lithium [20]. 
Lithium sulfide $\left(\mathrm{Li}_{2} \mathrm{~S}\right)$ has about four times higher theoretical capacity $(1166 \mathrm{mAh} / \mathrm{g})$ than that of commercial cathode materials, and also has a very high melting point $\left(938^{\circ} \mathrm{C}\right)$, which allows it to perform even at higher temperature. With the advantages of full lithiation of sulfur, $\mathrm{Li}_{2} \mathrm{~S}$ can also be paired with different anodes (e.g. tin, silicon, etc.) which eliminate dendrite formation and the safety issues of metallic lithium [21]. Moreover, $\mathrm{Li}_{2} \mathrm{~S}$, which has a low density than sulfur, undergoes volumetric contraction rather than expansion during charging and discharging, resulting in less structural damage to the cathode. Although $\mathrm{Li}_{2} \mathrm{~S}$ has a number of advantages over sulfur, it also has some challenges to overcome. Unlike sulfur, $\mathrm{Li}_{2} \mathrm{~S}$ is very sensitive to moisture and needs to be activated when coupled with anodes. It is also electronically and ionically nonconductive and has very large particle sizes [22].

Few efforts have been directed towards mitigating the aforementioned shortcomings of $\mathrm{Li}_{2} \mathrm{~S}$. Among them, Yang et al. [23] ball milled $\mathrm{Li}_{2} \mathrm{~S}$ and $\mathrm{Al}_{2} \mathrm{O}_{3}$ to reduce the size of the $\mathrm{Li}_{2} \mathrm{~S}$ particles and to increase the conductivity of the $\mathrm{Li}_{2} \mathrm{~S}$. Similar ball-milling approaches along with cathode fabrication in inert environment (glove box), high $1^{\text {st }}$ cycle activation voltage ( $\left.4 \mathrm{~V}\right)$ were adopted by other groups $[9,22$, 24] to fabricate $\mathrm{Li}_{2} \mathrm{~S}-\mathrm{C}$ composites with different carbon sources, to prevent moisture absorption and to activate the active material. Besides mechanical mixing and grinding processes, in-situ chemical processes were also adopted to fabricate fine-grained $\mathrm{Li}_{2} \mathrm{~S}-\mathrm{C}$ composite with increased conductivity $[25,26]$. However, none of their works focused on suitable carbon material selection through ball milling method along with high active material content.

In their methods, both the mechanical and the chemical processes, however, the electrodes were prepared by the conventional slurry casting method where a large proportion ( around 50\%) of the slurry consists of binder (e.g., poly(vinylide difluoride) (PVDF) and carboxymethyl cellulose (CMC)), solvents (e.g. N-methyl-2-pyrrolidone (NMP), and other conductive additives which has no positive contribution on discharge capacity. In some cases, the active material content is reduced to $30-40$ wt\% to accommodate the various additives. It has been found that, among these inactive materials, 
the binder has some adverse effects on cell performance. Most of the binders are insulating in nature and increase the internal resistance of the cell. Moreover, at high temperature, binders (e.g. PVDF) decompose into toxic compounds (e.g. hydrofluoric acid, fluorocarbons, etc.) [27, 28].

Eliminating the binder content is not the only way to increase the active material content and to achieve better capacity. A three-dimensional (3-D) interconnected metallic network such as nickel (Ni) foam has a large accessible surface area with high electrical conductivity, and can accommodate and utilize high amounts of active material. Researchers from all over the world [29-31] have focused their attention on 3-D network structures to load larger amounts of active material while maintain higher electrical conductivity, thermal stability, and structural integrity. They found that a 3-D interconnected network is an ideal means to allow the transport of electrons and ions during charging and discharging of a battery [32]. Very recently, some successful works have been conducted on 3-D Al-foam, Ni-foam and graphene aerogel, however, they used these 3-D network for impregnation of high amount sulfur rather than $\mathrm{Li}_{2} \mathrm{~S}$ [33-35].

Very few efforts have been directed independently towards the synthesis of $\mathrm{Li}_{2} \mathrm{~S}-\mathrm{C}$ composite through ball milling, designing binder-free $\mathrm{Li}_{2} \mathrm{~S}-\mathrm{C}$ composite, and applying 3-D network structures in the fabrication of $\mathrm{Li}_{2} \mathrm{~S}-\mathrm{C}$ composite electrode. It is necessary, however, to develop a systematic approach to finding suitable carbon sources for fabrication of $\mathrm{Li}_{2} \mathrm{~S}-\mathrm{C}$ composite through the ballmilling process. The usage of 3-D multi-layered $\mathrm{Ni}$ foam for encapsulation of $\mathrm{Li}_{2} \mathrm{~S}-\mathrm{C}$ composite to produce high active material content binder-free 3-D-structured cathode is reported for the first time here. In this work, microsized $\mathrm{Li}_{2} \mathrm{~S}$ powder was ball milled with four different carbon sources to synthesize $\mathrm{Li}_{2} \mathrm{~S}-\mathrm{C}$ composites, where smaller size $\mathrm{Li}_{2} \mathrm{~S}$ particles were mixed uniformly with conductive carbons. From physical and morphological examination, suitable carbon source was selected among the four carbons. The fabricated composites were then capillary-deposited in 3-D multi-layered Nifoam from a dioxolane (DOL)-containing mixture with high amount active material. To facilitated the electrochemical activation of $\mathrm{Li}_{2} \mathrm{~S}-\mathrm{C}$ composite by reducing the initial potential barrier, in the $1^{\text {st }}$ cycle 
the cells were charged to $3.5 \mathrm{~V}$ with a very low current density. In addition, a conductive, singlewalled carbon nanotube (SWCNT) free-standing layer with a refined, woven-like structure was inserted in between the cathode and the separator to improve the initial capacity and capacity retention. Finally, a comparative study was conducted to analyze the effects of binder and 3-D multilayered Ni-foam.

\section{Experimental:}

2.1 Synthesis of $\mathrm{Li}_{2} \mathrm{~S}$-Carbon Composite: Due to the sensitivity of $\mathrm{Li}_{2} \mathrm{~S}$ to moisture and air, the fabrication process and materials preparation were conducted inside an argon-filled glove-box. Commercial $\mathrm{Li}_{2} \mathrm{~S}$ was purchased from Sigma-Aldrich with larger mesh size $(10-20 \mu \mathrm{m})$, and a carbon source were ball-milled together in a planetary ball mill at $100 \mathrm{rpm}$, with a 10:1 ball to $\mathrm{Li}_{2} \mathrm{~S}$ weight ratio, to synthesize the $\mathrm{Li}_{2} \mathrm{~S}-\mathrm{C}$ composite. Same procedure and similar parameter were used for fabricating $\mathrm{Li}_{2} \mathrm{~S}-\mathrm{C}$ composite for four different carbon sources. The other ball-milling parameters were chosen from our previous work on $\mathrm{Li}-\mathrm{S}$ [36]. The ratio of $\mathrm{Li}_{2} \mathrm{~S}$ to carbon was 70:30. Four different carbon sources, carbon black (CB), activated carbon (AC), graphene (GP), and multi-walled carbon nanotube (MWCNT) were used for synthesizing four different $\mathrm{Li}_{2} \mathrm{~S}-\mathrm{C}$ composites. Among the four carbon sources, GP was synthesized in our laboratory through a modified Hummers' method [37], and the other three are commercial grade purchased from Sigma Aldrich.

2.2 Fabrication of $\mathrm{Li}_{2} \mathrm{~S}-\mathrm{C}$ composites encapsulated in 3-D Ni-foam electrode: First, the Ni foam was cut into circular disks with a diameter of $9.5 \mathrm{~mm}$. The average areal weight of each Ni-foam disk is around $25 \mathrm{mg} / \mathrm{cm}^{2}$. The disks were then washed with distilled water followed by ethanol. Then, the disks were put into an ethanol-containing beaker and sonicated for 10 minutes to remove all microsized contaminations. Then, the disks were dried at $80{ }^{\circ} \mathrm{C}$ for 24 hours under vacuum and transferred to the glove box. Before encapsulating the $\mathrm{Li}_{2} \mathrm{~S}-\mathrm{C}$ composites in the Ni-foam disks, the weight of the each disk was measured, in order to calculate the amount of active material that was loaded into each disk. For encapsulation of the active material, a certain amount of $\mathrm{Li}_{2} \mathrm{~S}-\mathrm{C}$ composite 
was mixed with DOL in a mortar. Then, the disks were dipped into the slurry to encapsulate the active material. Through capillary action, the pores of the Ni foam were filled with active materialcontained DOL which were later dried inside the glove box at room temperature. It should be noted that DOL, which is an organic compound, can sublime easily at room temperature. After the evaporation of DOL, the disks were mechanically pressed to entrap the active materials in the 3-D $\mathrm{Ni}$-foam. Each $9.5 \mathrm{~mm}$ disk electrode contained $\sim 5-6 \mathrm{mg}$ of active materials $\left(\mathrm{Li}_{2} \mathrm{~S}-\mathrm{C}\right)$. The sequence of active material loading into the $\mathrm{Ni}$ foam is shown in Figure S1 in the Supporting Information. For fabrication of $\mathrm{Li}_{2} \mathrm{~S}-\mathrm{C}$ composites with binder, polyvinylidene fluoride (PVDF) was added into the composite in such a way that the ratio of $\mathrm{Li}_{2} \mathrm{~S}$ to carbon to PVDF was kept at 60:30:10. A certain amount of mixture was mixed in a mortar with NMP to make slurry. When the PVDF was dissolved in the NMP, the disks were dipped into the mixture, which was followed by vacuum drying at $80{ }^{\circ} \mathrm{C}$ for 48 hours.

2.3 Fabrication of SWCNT free-standing layer: $15 \mathrm{mg}$ SWCNT with $500 \mathrm{ml}$ de-ionized water were poured into a beaker, and $500 \mathrm{mg}$ Triton-X100 surfactant was added. Then, the solution was probesonicated for $1 \mathrm{~h}$ with a $2 \mathrm{~s}$ pause time, followed by vacuum filtration and washing with de-ionized water and ethanol. The polytetrafluoroethylene (PTFE) filter paper with the SWCNT layer was dried under vacuum overnight at $60^{\circ} \mathrm{C}$, and finally, the SWCNT layer was easily peeled off from the filter paper [38, 39].

2.4 Fabrication of cells: The CR 2032 coin-type cells were assembled in an Ar-filled glove box, where discs of Li foil were used as the counter electrode and reference electrode. The electrolyte was prepared by dissolving $1 \mathrm{M}$ lithium bis(trifluoromethane sulfonyl)imide (LiTFSI) and $0.1 \mathrm{M} \mathrm{LiNO}_{3}$ in co-solvents of 1,3-dioxolane (DOL) and 1,2-dimethoxyethane (DME), with a volume ratio of 1:1 and the amount that was used for each coin cell was around 100-200 $\mu \mathrm{L}$. A porous polypropylene film was used as the separator. A SWCNT free-standing layer with an areal mass of $1.5 \mathrm{mg} / \mathrm{cm}^{2}$ and $1 \sim 3$ $\mu \mathrm{m}$ thickness was inserted in between the cathode and the separator in some cells. 
2.5 Characterization: To characterize the $\mathrm{Li}_{2} \mathrm{~S}-\mathrm{C}$ composite and Li-S cells, different analytical tools were used. For physical and morphological characterization of the composite, X-ray diffraction (XRD, GBC MMA 017) and field emission scanning electron microscopy (SEM; JEOL: FESEM-7500) were used. A scanning electron microscope was also used for conducting large-area energy dispersive Xray spectroscopy (EDS) mapping. For electrochemical performance evaluation of the Li-S cell, an automatic battery tester system (Land ${ }^{\bullet}$, China) was used at various current densities at room temperature. For testing the cycling performance, the cell was activated by charging it to $3.5 \mathrm{~V}$ with very low current density $\left(\mathrm{C} / 200,1 \mathrm{C}=1166 \mathrm{mAh} / \mathrm{g}_{\mathrm{Li}_{2}} \mathrm{~s}\right)$. From the following cycle, a conventional voltage window (1.7-3 V) was applied. Electrochemical impedance spectroscopy (EIS) and cyclic voltammetry (CV) measurements were performed on a Biologic VMP 3 electrochemical workstation over a frequency range of $10 \mathrm{mHz}$ to $100 \mathrm{kHz}$, and the scan rate was $0.05 \mathrm{mV}$ within a $1.5 \mathrm{~V}$ to $4 \mathrm{~V}$ voltage window.

\section{Results and Discussion:}

Figure 1: XRD patterns of $\mathrm{Li}_{2} \mathrm{~S}-\mathrm{C}$ composites.

The X-ray diffraction (XRD) patterns of all $\mathrm{Li}_{2} \mathrm{~S}-\mathrm{C}$ composites, along with commercial $\mathrm{Li}_{2} \mathrm{~S}$, are shown in Figure 1, which clearly shows that all four composites exhibit characteristics peaks of $\mathrm{Li}_{2} \mathrm{~S}$. As is well known, $\mathrm{Li}_{2} \mathrm{~S}$ has an antifluorite structure and has higher atomic packing density on the (111), (200), and (311) planes, and for this reason, all the major peaks for $\mathrm{Li}_{2} \mathrm{~S}$ come from the (111), (200), and (311) planes [40]. The intensity of the peaks for all four composites looks similar, however, except for $\mathrm{Li}_{2} \mathrm{~S}-\mathrm{MWCNT}$, where the peak intensities are much smaller than for the other composites, which means that, in $\mathrm{Li}_{2} \mathrm{~S}-\mathrm{MWCNT}$ composite, $\mathrm{Li}_{2} \mathrm{~S}$ has less favorable condition to reflect the X-ray beams from those particular planes. In other words, it can be said that MWCNT, which has a very high aspect ratio (length to diameter ratio), managed to adhere and successfully cover the $\mathrm{Li}_{2} \mathrm{~S}$ particles, reducing the intensity. It should be mentioned that all the samples were covered with 
Kaptontape before the XRD analysis due to the sensitivity to moisture and air of $\mathrm{Li}_{2} \mathrm{~S}$. Figure $\mathrm{S} 2$ shows the XRD sample preparation using Kapton tape.

Field emission SEM (FESEM) micrographs of the four carbon sources are presented in Figure S3, which clearly shows the sizes and structures of the four different carbons. CB particles look spherical, whereas AC particles have an arbitrary flake shape. On the other hand, GP is in the form of agglomerated two-dimensional sheets, and MWCNT has a fiber-like structure with a very high aspect (length to diameter) ratio. These FESEM images were of help in analyzing the morphology of the ball-milled $\mathrm{Li}_{2} \mathrm{~S}-\mathrm{C}$ composites that have been fabricated using those four carbon sources.

Figure 2: FESEM images of a) $\mathrm{Li}_{2} \mathrm{~S}, \mathrm{~b}$ ) $\left.\mathrm{Li}_{2} \mathrm{~S}-\mathrm{CB}, \mathrm{c}\right) \mathrm{Li}_{2} \mathrm{~S}-\mathrm{AC}$, d) $\mathrm{Li}_{2} \mathrm{~S}-\mathrm{GP}$, and e, f) $\mathrm{Li}_{2} \mathrm{~S}-\mathrm{MWCNT}$ composites (Scale bars are $1 \mu \mathrm{m}$ for Figures-a, b, c, d, e and $100 \mathrm{~nm}$ for Figure-f).

Figure 2 shows the morphology of the ball-milled composites along with pristine $\mathrm{Li}_{2} \mathrm{~S}$. It is clearly shown in Figure $2 \mathrm{~b}$ and $2 \mathrm{c}$ that $\mathrm{CB}$ and $\mathrm{AC}$ are discretely dispersed and do not adhere to the $\mathrm{Li}_{2} \mathrm{~S}$ particles. This is because the $C B$ and $A C$ are much smaller in size compared to $\mathrm{Li}_{2} \mathrm{~S}$, and the percentage of carbon that has been added into the composite, which is $30 \mathrm{wt} \%$, is not sufficient to cover the larger size $\mathrm{Li}_{2} \mathrm{~S}$ particles. On the other hand, the same amounts (30 wt\%) of GP and MWCNT not only firmly adhere to the $\mathrm{Li}_{2} \mathrm{~S}$, but also covers the $\mathrm{Li}_{2} \mathrm{~S}$ particles, as is shown in Figure $2 \mathrm{~d}$ and 2e. Moreover, the MWCNT covers each $\mathrm{Li}_{2} \mathrm{~S}$ particles completely because of its very high aspect ratio, which can reduce the insulation problem with $\mathrm{Li}_{2} \mathrm{~S}$. From the FESEM micrograph, it can be predicted that the $\mathrm{Li}_{2} \mathrm{~S}-\mathrm{MWCNT}$ composite should have better electrochemical performance compared to the remaining three composites. For further confirmation of the distribution of the $\mathrm{Li}_{2} \mathrm{~S}$ particles and the carbon sources in the composite, energy dispersive spectroscopy (EDS) analysis was carried out and is shown in Figure S4. EDS mapping clearly shows that both sulfur and carbon coexist in the composite, and in most cases, they are embedded in each other. 
Before analyzing the electrochemical performance of $\mathrm{Li}_{2} \mathrm{~S}-\mathrm{C}$ composites cathode, it is worthwhile to mention that conventional $\mathrm{Li}_{2} \mathrm{~S}-\mathrm{C}$ composite cathodes are prepared from slurry which contains active materials, binder, solvent, and other ingredients. This slurry is then pasted onto a two dimensional aluminum foil current collector. It is worthwhile to mention here that the aluminum foil current collector is a two dimensional (2-D) sheet and can be loaded with only a very limited amount of active materials, and in most cases, it can be loaded with $1 \mathrm{mg}$ or less of the active material. Moreover, it is mandatory to add binder and solvent to achieve a firm bonding between the 2-D current collector and the active materials. Sometimes other ingredients are also used to achieve better interfacial bonding between the current collector and the active materials, $[24,41]$ which not only reduces the active material content, but also increases the internal resistance of the cell. Furthermore, the binders, solvents, and other ingredients cost extra money, which could be a stumbling block for commercialization.

Table 1: Comparison of properties and performance of $\mathrm{Li}_{2} \mathrm{~S}-\mathrm{C}$ composites for Li-S battery.

Table 1 tabulates the relationships among the active material content, current collector, binder content, and the discharge capacity in the most recent papers investigating $\mathrm{Li}_{2} \mathrm{~S}-\mathrm{C}$ composite cathode. It clearly shows that, for fabrication of $\mathrm{Li}_{2} \mathrm{~S}-\mathrm{C}$ composite cathode, different binders were used in almost every case and achieved allowable discharge capacity. It is also noticeable from Table 1 that, in all the works on $\mathrm{Li}_{2} \mathrm{~S}$ that are currently available from open sources, their conventional 2-D current collector can barely be loaded with $1.5 \mathrm{mg} / \mathrm{cm}^{2}$ active materials. To increase the active material content, a 3-D network or framework needs to be considered. The use of 3-D conductive network materials in battery application is a promising feature that has already been used on several occasions. Xi et al. [27] used a 3-D graphene network to produce binder-free sulfur cathode. Zhao and Sa $[42,43]$ used 3-D Ni foam as a framework for the electrodeposition of sulfur materials and as current collector, respectively. All of them managed to achieve better electrochemical performance compared to that with a conventional 2-D Al-foil current collector. 
Figure 3: FESEM image of a) Ni-foam, and b, c) top view and side view images of $\mathrm{Li}_{2} \mathrm{~S}-\mathrm{MWCNT}$ composite cathode, where the active material was loaded in Ni-foam through powder dispersion; $d$, e) top view and side view images of $\mathrm{Li}_{2} \mathrm{~S}-\mathrm{MWCNT}$ composite cathode where the active material was loaded in Ni-foam through capillary deposition Scale bars for all the figures are $100 \mu \mathrm{m}$ ).

3-D Ni-foam, which consists of several layers and many micropores, can accommodate a large amount of active materials and can maintain its structural integrity after active material loading. Figure 3a presents a micrograph of the pristine Ni-foam where a microporous 3-D layered network structure is clearly visible. The lodgment of the active material in the foam has been done into two different ways, which are direct dispersion and capillary deposition. In both cases, the cathodes were pressed after the active material loading to achieve better mechanical confinement and interfacial bonding between the $\mathrm{Ni}$-foam and the active material. Figure $3 \mathrm{~b}$ and $3 \mathrm{c}$ respectively shows a top and side view of the morphology after direct active material dispersion (conventional dispersion method). From these two images, it is clear that the conventional deposition method is not suitable for loading high amount active material. The micro-sized $\mathrm{Li}_{2} \mathrm{~S}$ powder particles and carbon particles adhered to each other and failed to penetrate the Ni-foam pores. For this reason, most of the pores remained empty, and small amounts of active materials just adhered to the top of the Ni-foam surface. The side view (Figure 3c) shows that the materials cannot percolate to every layer, which reduces the active material content. On the other hand, the capillary deposition method can load more active material and provide better interfacial bonding. In the capillary deposition method, the active material can be loaded into each layer of the foam due to capillary action, which is unlikely to happen in the direct dispersion method. Figure $3 \mathrm{~d}$ and $3 e$ shows front and side views of a capillary deposited cathode and reveals that the active material is loaded into each layer of the foam. On top of that, due to capillary action, all the pores are completely filled by the active materials, which increased the active material content. It is important to mention here that $\mathrm{DOL}$ is an electrolytic compound that is used in the capillary deposition method as a solvent and is later evaporated, so that the active material is entrapped in the Ni-foam network. Moreover, DOL, which 
is liquid at room temperature $\left(25^{\circ} \mathrm{C}\right)$ and pressure $(1 \mathrm{~atm})$ does not react with the cathode surface and active materials.

With the help of this capillary deposition method, large amounts of active materials were deposited in the Ni-foam, and in every case, $5 \mathrm{mg} / \mathrm{cm}^{2}$ and more $\left(5\right.$ to $6 \mathrm{mg} / \mathrm{cm}^{2}$ ) of the active materials were loaded in each electrode (9.5 $\mathrm{mm}$ diameter disk), which is the maximum amount compared to the all other results that are available from open sources. After the active material loading process, the electrochemical performance of the electrodes was evaluated for all four different carbon sources, and the best $\mathrm{Li}_{2} \mathrm{~S}-\mathrm{C}$ composite was found among them. Unlike sulfur-carbon cathode, $\mathrm{Li}_{2} \mathrm{~S}-\mathrm{C}$ cathode is fabricated in the discharged state and needs to be activated before measuring its electrochemical performance.

For activating the $\mathrm{Li}_{2} \mathrm{~S}-\mathrm{C}$ cathode, an upper high cut-off voltage $\left(\sim 4 \mathrm{~V}_{\mathrm{Li}}\right)$ is usually applied by the researchers. They believed that the initial high cut-off voltage for charging promoted phase nucleation of the two-phase reaction between $\mathrm{Li}_{2} \mathrm{~S}$ and polysulfides [23]. At $4 \mathrm{~V}$, however, most of the ether-based electrolytes are not stable and start to dissociate. For this reason, researchers have tried to avoid a high cut-off voltage for the activation process [44]. They tried to use a redoxmediator in electrolyte, which can allow the recovery of most of the $\mathrm{Li}_{2} \mathrm{~S}$ theoretical capacity in the activation cycle at potentials as low as $2.9 \mathrm{~V}_{\mathrm{L}}$.

Yang et al. [23] reported that the current density during first charging has a significant effect on the activation of the $\mathrm{Li}_{2} \mathrm{~S}-\mathrm{C}$ cathode. They found a linear relationship between the overpotential and the current rate. They also claimed that the overpotential, which is the energy needed for phase nucleation to reduce the initial potential barrier, remains nearly constant and is quite small at low current. Inspired by their work, we used a very low current density $(C / 200)$ for the first cycle to activate the cathode. On top of that, we charged the cell to $3.5 \mathrm{~V}$ instead of $4 \mathrm{~V}$ for the first cycle. It is found that, in most cases $\mathrm{Li}_{2} \mathrm{~S}$ is activated at $3.5 \mathrm{~V}$ when a very low current density is applied which 
will protect the electrolyte from being dissociated. In the following cycles, the cathode need not be activated at $3.5 \mathrm{~V}$, and hence, a conventional voltage window (1.7-3 V) was applied.

Figure 4: (a) Charge discharge profile of first cycle for activation of $\mathrm{Li}_{2} \mathrm{~S}-\mathrm{MWCNT}$ composite (b) Cycling performance of $\mathrm{Li}_{2} \mathrm{~S}-\mathrm{C}$ composites at the $0.1 \mathrm{C}$ rate.

The charge discharge profile of the activation process is shown in Figure 4a, where the cell was charged to $3.5 \mathrm{~V}$ with a current density of $\mathrm{C} / 200$. In the charging profile, it is seen that, the voltage is rapidly increased to $3.25 \mathrm{~V}$ at the beginning of the charging and then dropped down to $3 \mathrm{~V}$ followed by gradual increment to $3.5 \mathrm{~V}$. The initial rapid increment of voltage is known as the initial potential barrier of the cell which usually varies on the current density the charging. It is well known that the most suitable voltage window for ether-based electrolyte for the Li-S system is $1.5 \mathrm{~V}$ to $3 \mathrm{~V}$, and Meini et al. [44] showed that the energy band gap between highest occupied molecular orbital (HUMO) and lowest unoccupied molecular orbital (LUMO) for ether-based electrolyte is around 44.5V but it can hardly be used this voltage window due to the formation of thick solid electrolyte interface (SEI). There is an inverse relationship between SEI thickness and electrolyte band gap. In most of the Li/S system, the SEI thickness is quite high which force to reduce the voltage window and beyond 3.6 V, the ether-based electrolyte in Li/S system starts to dissociate [45]. It is also shown in Figure 4a that, at $3.5 \mathrm{~V}$ upper cut-off voltages, the cell can achieve $990 \mathrm{mAh} / \mathrm{g}$ charge capacity, which is very close to $\mathrm{Li}_{2} \mathrm{~S}$ theoretical capacity $(1166 \mathrm{mAh} / \mathrm{g})$. So, it can be said from above discussion that, it is possible to activate $\mathrm{Li}_{2} \mathrm{~S}-\mathrm{C}$ composites at $3.5 \mathrm{~V}$. This low voltage activation phenomenon has a substantial influence towards obtaining better discharge capacity.

Beside the activation charging profile, Figure $4 \mathrm{a}$ shows the discharge profiles of the $\mathrm{Li}_{2} \mathrm{~S}-\mathrm{C}$ composites, and as expected, the discharge profiles of the $\mathrm{Li}_{2} \mathrm{~S}-\mathrm{C}$ composites for both activation processes are similar to the discharge profile of the conventional Li-S cell. In the discharge curves, two plateaus are observed, with the first plateau related to the transformation from elemental sulfur to long chain lithium polysulfides $\left(\mathrm{Li}_{2} \mathrm{~S}_{n}, \mathrm{n} \geq 4\right)$, and the second plateaurepresenting the 
reduction of long chain lithium polysulfides to short chain lithium polysulfides $\left(\mathrm{Li}_{2} \mathrm{~S}_{n}, \mathrm{n}<4\right)$. After the activation process, all four $\mathrm{Li}_{2} \mathrm{~S}-\mathrm{C}$ composites were tested for cycling performance, and the results are shown in Figure $4 \mathrm{~b}$. $\mathrm{Li}_{2} \mathrm{~S}-\mathrm{AC}$ and $\mathrm{Li}_{2} \mathrm{~S}-\mathrm{CB}$ show higher initial capacity of $945 \mathrm{mAh} / \mathrm{g}$ and 906 $\mathrm{mAh} / \mathrm{g}$, respectively, compared to $\mathrm{Li}_{2} \mathrm{~S}-\mathrm{GP}$ and $\mathrm{Li}_{2} \mathrm{~S}-\mathrm{MWCNT}$ with $860 \mathrm{mAh} / \mathrm{g}$ and $888 \mathrm{mAh} / \mathrm{g}$, respectively. $\mathrm{Li}_{2} \mathrm{~S}-\mathrm{MWCNT}$ shows the highest capacity retention of $50.7 \%$, however, followed by $\mathrm{Li}_{2} \mathrm{~S}$ GP (40.9\%), $\mathrm{Li}_{2} \mathrm{~S}-\mathrm{AC}(25 \%)$, and $\mathrm{Li}_{2} \mathrm{~S}-\mathrm{CB}(21.3 \%)$ after 100 cycles. It was expected from the morphology of this composite, where the $\mathrm{Li}_{2} \mathrm{~S}$ was fully covered and adhered to by MWCNT, that the $\mathrm{Li}_{2} \mathrm{~S}-\mathrm{MWCNT}$ would exhibit better electrochemical performance compared to the other three composites. It is necessary to mention here that, compared to the other works on the $\mathrm{Li}_{2} \mathrm{~S}$ battery listed in Table 1, the discharge capacity has not significantly improved however, considering active material content which is $5 \mathrm{mg} / \mathrm{cm}^{2}$; this is the highest discharge capacity that is available when compared to reports in open sources. It can be concluded here that $\mathrm{Li}_{2} \mathrm{~S}-\mathrm{MWCNT}$ composite has better characteristics in terms of morphological and electrochemical performance, and in the following part of this paper; we shall focus only on $\mathrm{Li}_{2} \mathrm{~S}-\mathrm{MWCNT}$ composite for further characterization and improvement.

Figure 5: (a) Charge-discharge profiles, and (b) rate capability of Li $2 \mathrm{~S}-\mathrm{MWCNT}$ composite.

Figure $5 a$ and $5 b$, respectively, shows representative charge-discharge profiles and the rate capability of $\mathrm{Li}_{2} \mathrm{~S}-\mathrm{MWCNT}$ composite. The discharge plateau shows that there is no drastic voltage drop in the discharge profile, indicating very low polarization loss (both activation polarization and concentration polarization) along with internal impedance loss. The latter one can also be determined from electrochemical impedance spectroscopy (EIS), which will be discussed in a later part of the paper. $\mathrm{Li}_{2} \mathrm{~S}-\mathrm{MWCNT}$ composite also shows high capacity at higher current density. The cells were tested at different current densities, varying from $0.1 \mathrm{C}$ to $5 \mathrm{C}$, and the results show that, even at the $3 C$ and $5 C$ rates, the cells can exhibit a capacity of $300 \mathrm{mAh} / \mathrm{g}$ and $80 \mathrm{mAh} / \mathrm{g}$, respectively. It is notable that, in most of the papers on $\mathrm{Li}_{2} \mathrm{~S}-\mathrm{C}$ composite, the authors conducted 
their testing with a maximum current density of $2 \mathrm{C}$, and in most of cases, our $\mathrm{Li}_{2} \mathrm{~S}-\mathrm{MWCNT}$ composite shows much better rate capability than in other works $[25,46]$. This exceptionally high rate performance may be achieved because of the structural benefit of the 3-D network of Ni-foam along with better carbon sources. This combination not only improved the conductivity of the composite, but also maintained a 3-D conductive network that acted as a better current collector, as well as helping to utilize a higher amount of active materials. In Figure-5b capacity fading seems violent when the current density is back to $0.1 \mathrm{C}$ from $5 \mathrm{C}$. However, it is not true in the real case and it can be explained in this way that, when there is sudden change of reaction time of $\mathrm{Li}^{+}$ion which is 50 times increment (from $0.1 \mathrm{C}$ from $5 \mathrm{C}$ ), most of the $\mathrm{Li}^{+}$ion can get back their own position and results higher reversible capacity than the usual cycling performance and from the next few cycles the capacity start to decay with the normal rate. To justify the above statement, Figure $4 \mathrm{~b}$ and Figure $5 \mathrm{~b}$ that show the cycling performance (at $0.1 \mathrm{C}$ ) and rate capability (different current density) can be compared. The capacity gain after 35 cycles that shown in Figure-5b is almost similar to the capacity after 35 cycles in Figure-4b. This means that, the rapid capacity fading that has been observed when current density back to $0.1 \mathrm{C}$ from $5 \mathrm{C}$ is due to high reversible capacity gain with sudden change $\mathrm{Li}^{+}$movement rate.

Figure 6: a) Cyclic voltammetry (CV) curves for the first 4 cycles and b) electrochemical impedance spectra (EIS) of Li ${ }_{2} \mathrm{~S}-M W C N T$ composite. The inset to the EIS spectra is the Z-Fit equivalent circuit.

Table 2:Z-fitted EIS results for Li 2 S-MWCNT composite.

Figure 6a shows cyclic voltammograms of $\mathrm{Li}_{2} \mathrm{~S}-\mathrm{MWCNT}$ composite for the first 4 cycles with $0.05 \mathrm{mV}$ $\mathrm{s}^{-1}$ scan rate, in which two reduction peaks and one oxidation peak are observed. The first cycle shows a small oxidation peak at $3.5 \mathrm{~V}$, however, along with a very sharp peak at $2.5 \mathrm{~V}$. Yang et al. [23] showed that the peak at $3.5 \mathrm{~V}$ indicates the necessity of overpotential to overcome the initial barrier. The EIS results shown in Figure $6 \mathrm{~b}$ are impedance spectra of $\mathrm{Li}_{2} \mathrm{~S}-\mathrm{MWCNT}$ composite (with and without binder) as cathode, while the inset in Figure $6 \mathrm{~b}$ shows the Z-fitted equivalent circuit 
forthe composite, where the resistance $(R)$, constant phase element $\left(\mathrm{CPE} \approx \mathrm{Q}_{2}\right)$, and Warburg impedance element $(W)$ are included. $R_{\mathrm{e}}(\sim \mathrm{R} 1)$ and $R_{\mathrm{ct}}(\sim \mathrm{R} 2)$ represent the solution resistance of the electrolyte and the charge transfer resistance along with the surface resistance, respectively. Q2 represents the $\mathrm{CPE}$, whichis related to the solid-state diffusion of $\mathrm{Li}^{+}$due to the formation of a double layer capacitor between the electrolyte and the cathode interface. $W$ is the Warburg impedance element attributable to the diffusion of lithium ions in the active materials. The Z-fitted values of the EIS curves for $\mathrm{Li}_{2} \mathrm{~S}-\mathrm{MWCNT}$ composite with binder and without binder are shown in Table 2. Both EIS curves show similar depressed semicircles with similar values of $R_{\mathrm{e}}$ and CPE. The charge transfer resistance $\left(R_{\mathrm{ct}}\right)$ and Warburg impedance $(W)$, however, are much higher for $\mathrm{Li}_{2} \mathrm{~S}$ MWCNT composite with binder than without binder. This is because the polymeric binders are electrical insulators, which impedes the Li ionic movement, as well as electron, movement inside the cell. This is because, linear-chain PVDF is a polar compound with a dipole moment of 2.1D and due to the high dipole moment, PVDF shows significant attraction to the positive Li ion which will impede Li-ion movement in the cathode material. It is important to mention here that the values of $R_{\mathrm{e}}$ and CPE remain the same for both cases, which is due to the structural benefit of the electrode. It is proposed that the 3-D Ni-foam network helps to diffuse $\mathrm{Li}^{+}$without increasing the thickness of the solid electrolyte interphase (SEI) and the double layer capacitor.

From Figure 4 and Figure 5, it is obvious that, as in the case of the Li-S cell, the capacity decay with cycle number is also an important issue for $\mathrm{Li}_{2} \mathrm{~S}-\mathrm{C}$ composite. The main reason behind the capacity fading is the dissolution of polysulfide into the electrolyte, which causes the so-called shuttle phenomenon. To improve the initial capacity and the capacity retention, a free-standing layer (FSL) of single-walled carbon nanotube (SWCNT) was inserted in between the separator and the cathode, which can increase the conductivity of the sulfur results, high amount active material utilization. This novel approach was first introduced by Manthiram's group [47], and later, it was also adopted by other groups $[48,49]$ to achieve higher initial capacity and better capacity retention for the Li-S 
battery. Although there are many similarities between elemental sulfur and $\mathrm{Li}_{2} \mathrm{~S}$, this novel approach has not been used for $\mathrm{Li}_{2} \mathrm{~S}-\mathrm{C}$ composite.

Figure 7: Cycling performance at the $0.1 \mathrm{C}$ rate of $\mathrm{Li}_{2} \mathrm{~S}-\mathrm{MWCNT}$ composite with binder and FSL.

Figure 7 shows the cycling performance of the FSL-containing Li ${ }_{2} \mathrm{~S}-\mathrm{MWWCNT}$ composite, where the FSL was inserted in between the cathode and the separator. Moreover, the cycling performances of $\mathrm{Li}_{2} \mathrm{~S}$ MWCNT composite with binder (10 wt\% binder) and the bare Li $2 \mathrm{~S}-\mathrm{MWCNT}$ composite are shown in the Figure for comparison to justify the EIS results that are shown in Table 2. The Figure shows that, with the insertion of a FSL, the initial capacity rises to $1146 \mathrm{mAh} / \mathrm{g}_{\mathrm{Li}_{2} \mathrm{~S}}$, and capacity of $571 \mathrm{mAh} / \mathrm{g}_{\mathrm{Li}_{2} \mathrm{~S}}$ is retained after 100 cycles, which is almost 13\% higher than without FSL. It is also shown in Figure 7 that the addition of binder makes no significant difference to the cycling performance of the $\mathrm{Li}_{2} \mathrm{~S}$ MWCNT composite. In terms of capacity retention, however, Li $2 \mathrm{~S}-\mathrm{MWCNT}$ shows $7 \%$ more capacity under the same conditions than binder-containing $\mathrm{Li}_{2} \mathrm{~S}-\mathrm{MWCNT}$ composite. Figure $\mathrm{S} 5$ presents a FESEM image of binder-free $\mathrm{Li}_{2} \mathrm{~S}-\mathrm{MWCNT}$ composite cathode after 100 cycles, and it clearly shows that the cathode maintains its structural integrity even after 100 cycles. This Figure also shows that, unlike the pristine cathode, the active material of the cathode after cycling does not show cracking and agglomeration. The reason behind this phenomenon is that the continuous contraction and expansion of the active material during cycling and the percolation of electrolyte through the cracks disintegrates the active material, which increases the active surface area and facilitates the redox reactions, resulting in higher capacity. Hence, it can be said that the 3-D Ni-foam can not only hold a higher amount of active material, but also can maintain the structural integrity of the cathode with just its layered network structure, without the use of any binder.

\section{Conclusion:}

Binder-free $\mathrm{Li}_{2} \mathrm{~S}-\mathrm{C}$ composites were synthesized through a high energy ball-milling process with different carbon sources. These composites were then capillary-deposited in 3-D Ni-foam networks. 
Then, the composites were characterized physically, morphologically, and electrochemically. From the characterizations, it is found that $\mathrm{Li}_{2} \mathrm{~S}-\mathrm{MWCNT}$ composite shows much better morphology and performances than those of other composites. Later, the performance of the $\mathrm{Li}_{2} \mathrm{~S}-\mathrm{MWCNT}$ composite was further improved by inserting a vacuum-filtrated SWCNT free-standing layer in between the cathode and the separator. After insertion of the FSL, the initial capacity of the $\mathrm{Li}_{2} \mathrm{~S}-$ MWCNT composite was raised to $1146 \mathrm{mAh} / \mathrm{g}_{\mathrm{Li}_{2}} \mathrm{~s}$, which is equivalent to $1646 \mathrm{mAh} / \mathrm{gs}_{\mathrm{s}}$ for the Li-S system. Besides superior cycling performance, another important phenomenon is achieved in this work which is the loading of large amount active material $\left(\sim 5-6 \mathrm{mg} / \mathrm{cm}^{2}\right)$ into the 3-D Ni-foam electrode. The amount of active material that was loaded into each cathode was at least five times higher than that of conventional electrode with a 2-D aluminum-foil current collector. Furthermore, the structural integrity of the 3-D Ni-foam cathode without binder shows similar morphology compare to with binder3-D Ni-foam cathode, even after 100 cycles.

\section{Acknowledgements:}

The authors gratefully acknowledge the financial support provided by the Automotive Cooperative Research Centre (Grant number: Auto CRC 2020) and the support from the Institute for Superconducting and Electronic Materials (ISEM) and the Electron Microscopy Centre (EMC) at the University of Wollongong. The authors also thank Dr. Tania Silver for critical reading of the manuscript.

\section{References}

[1] Armand M, Tarascon JM. Building better batteries. Nature. 2008;451(7179):652-7.

[2] Ji X, Lee KT, Nazar LF. A highly ordered nanostructured carbon-sulphur cathode for lithium-sulphur batteries. Nat Mater. 2009;8(6):500-6. 
[3] Bruce PG, Freunberger SA, Hardwick LJ, Tarascon J-M. Li-O2 and Li-S batteries with high energy storage. Nat Mater. 2012;11(1):19-29.

[4] Moon S, Jung YH, Jung WK, Jung DS, Choi JW, Kim DK. Encapsulated Monoclinic Sulfur for Stable Cycling of Li-S Rechargeable Batteries. Adv Mater. 2013;25(45):6547-53.

[5] $\mathrm{Zu} \mathrm{C}$, Manthiram A. Hydroxylated Graphene-Sulfur Nanocomposites for High-Rate Lithium-Sulfur Batteries. Advanced Energy Materials. 2013;3(8):1008-12.

[6] Wang L, Dong Z, Wang D, Zhang F, Jin J. Covalent Bond Glued Sulfur NanosheetBased Cathode Integration for Long-Cycle-Life Li-S Batteries. Nano Lett. 2013;13(12):6244-50.

[7] Lin Z, Liu ZC, Fu WJ, Dudney NJ, Liang CD. Lithium Polysulfidophosphates: A Family of Lithium-Conducting Sulfur-Rich Compounds for Lithium-Sulfur Batteries. Angew Chem Int Edit. 2013;52(29):7460-3.

[8] Ji LW, Rao MM, Aloni S, Wang L, Cairns EJ, Zhang YG. Porous carbon nanofibersulfur composite electrodes for lithium/sulfur cells. Energ Environ Sci. 2011;4(12):5053-9. [9] Cai KP, Song MK, Cairns EJ, Zhang YG. Nanostructured Li2S-C Composites as Cathode Material for High-Energy Lithium/Sulfur Batteries. Nano Lett. 2012;12(12):6474-9. [10] Wang L, Wang D, Zhang F, Jin J. Interface Chemistry Guided Long-Cycle-Life Li-S Battery. Nano Lett. 2013;13(9):4206-11.

[11] Liang X, Zhang M, Kaiser MR, Gao X, Konstantinov K, Tandiono R, et al. Split-halftubular polypyrrole@sulfur@polypyrrole composite with a novel three-layer-3D structure as cathode for lithium/sulfur batteries. Nano Energy. 2015;11(0):587-99.

[12] Liang X, Kaiser M, Konstantinov K, Tandiono R, Wang Z, Liu H-K, et al. High performance pure sulfur honeycomb-like architectures synthesized by a cooperative selfassembly strategy for lithium-sulfur batteries. Rsc Adv. 2014;4(69):36513-6. 
[13] Hagen M, Dörfler S, Fanz P, Berger T, Speck R, Tübke J, et al. Development and costs calculation of lithium-sulfur cells with high sulfur load and binder free electrodes. J Power Sources. 2013;224(0):260-8.

[14] Jeddi K, Sarikhani K, Qazvini NT, Chen P. Stabilizing lithium/sulfur batteries by a composite polymer electrolyte containing mesoporous silica particles. J Power Sources. 2014;245(0):656-62.

[15] Song M-K, Zhang Y, Cairns EJ. A Long-Life, High-Rate Lithium/Sulfur Cell: A Multifaceted Approach to Enhancing Cell Performance. Nano Lett. 2013;13(12):5891-9.

[16] Li G-C, Li G-R, Ye S-H, Gao X-P. A Polyaniline-Coated Sulfur/Carbon Composite with an Enhanced High-Rate Capability as a Cathode Material for Lithium/Sulfur Batteries. Advanced Energy Materials. 2012;2(10):1238-45.

[17] Wang J, Chew SY, Zhao ZW, Ashraf S, Wexler D, Chen J, et al. Sulfur-mesoporous carbon composites in conjunction with a novel ionic liquid electrolyte for lithium rechargeable batteries. Carbon. 2008;46(2):229-35.

[18] Wang JZ, Lu L, Choucair M, Stride JA, Xu X, Liu HK. Sulfur-graphene composite for rechargeable lithium batteries. J Power Sources. 2011;196(16):7030-4.

[19] Wang J, Chen J, Konstantinov K, Zhao L, Ng SH, Wang GX, et al. Sulphurpolypyrrole composite positive electrode materials for rechargeable lithium batteries. Electrochim Acta. 2006;51(22):4634-8.

[20] Lin Z, Liu ZC, Dudney NJ, Liang CD. Lithium Superionic Sulfide Cathode for AllSolid Lithium-Sulfur Batteries. Acs Nano. 2013;7(3):2829-33.

[21] Hayashi A, Ohtsubo R, Ohtomo T, Mizuno F, Tatsumisago M. All-solid-state rechargeable lithium batteries with Li2S as a positive electrode material. J Power Sources. 2008;183(1):422-6. 
[22] Takeuchi T, Sakaebe H, Kageyama H, Senoh H, Sakai T, Tatsumi K. Preparation of electrochemically active lithium sulfide-carbon composites using spark-plasma-sintering process. J Power Sources. 2010;195(9):2928-34.

[23] Yang Y, Zheng GY, Misra S, Nelson J, Toney MF, Gui Y. High-Capacity Micrometer-Sized Li2S Particles as Cathode Materials for Advanced Rechargeable LithiumIon Batteries. J Am Chem Soc. 2012;134(37):15387-94.

[24] Guo JC, Yang ZC, Yu YC, Abruna HD, Archer LA. Lithium-Sulfur Battery Cathode Enabled by Lithium-Nitrile Interaction. J Am Chem Soc. 2013;135(2):763-7.

[25] Nan CY, Lin Z, Liao HG, Song MK, Li YD, Cairns EJ. Durable Carbon-Coated Li2S Core-Shell Spheres for High Performance Lithium/Sulfur Cells. J Am Chem Soc. 2014;136(12):4659-63.

[26] Zheng SY, Chen Y, Xu YH, Yi F, Zhu YJ, Liu YH, et al. In Situ Formed Lithium Sulfide/Microporous Carbon Cathodes for Lithium-Ion Batteries. Acs Nano. 2013;7(12):10995-1003.

[27] Xi K, Kidambi PR, Chen R, Gao C, Peng X, Ducati C, et al. Binder free threedimensional sulphur/few-layer graphene foam cathode with enhanced high-rate capability for rechargeable lithium sulphur batteries. Nanoscale. 2014;6(11):5746-53.

[28] Wang C, Wang X, Yang Y, Kushima A, Chen J, Huang Y, et al. Slurryless Li2S/Reduced Graphene Oxide Cathode Paper for High-Performance Lithium Sulfur Battery. Nano Lett. 2015;15(3):1796-802.

[29] Dang L, Wei C, Ma H, Lu Q, Gao F. Three-dimensional honeycomb-like networks of birnessite manganese oxide assembled by ultrathin two-dimensional nanosheets with enhanced Li-ion battery performances. Nanoscale. 2015;7(17):8101-9.

[30] Mao S, Lu G, Chen J. Three-dimensional graphene-based composites for energy applications. Nanoscale. 2015;7(16):6924-43. 
[31] Lingappan N, Van NH, Lee S, Kang DJ. Growth of three dimensional flower-like molybdenum disulfide hierarchical structures on graphene/carbon nanotube network: An advanced heterostructure for energy storage devices. J Power Sources. 2015;280(0):39-46.

[32] Rolison DR, Long JW, Lytle JC, Fischer AE, Rhodes CP, McEvoy TM, et al. Multifunctional 3D nanoarchitectures for energy storage and conversion. Chem Soc Rev. 2009;38(1):226-52.

[33] Cheng X-B, Peng H-J, Huang J-Q, Zhu L, Yang S-H, Liu Y, et al. Three-dimensional aluminum foam/carbon nanotube scaffolds as long- and short-range electron pathways with improved sulfur loading for high energy density lithium-sulfur batteries. J Power Sources. 2014;261:264-70.

[34] Cheng JJ, Zhu JT, Pan Y, Ma ZS, Song HJ, Pan JA, et al. Sulfur-Nickel Foam as Cathode Materials for Lithium-Sulfur Batteries. ECS Electrochemistry Letters. 2015;4(2):A19-A21.

[35] Rehman S, Guo S, Hou Y. Rational Design of Si/SiO2@Hierarchical Porous Carbon Spheres as Efficient Polysulfide Reservoirs for High-Performance Li-S Battery. Adv Mater. 2016: doi:10.1002/adma.201506111.

[36] Kaiser MR, Wang J, Liang X, Liu H-K, Dou S-X. A systematic approach to high and stable discharge capacity for scaling up the lithium-sulfur battery. J Power Sources. 2015;279(0):231-7.

[37] Li X, Wang X, Zhang L, Lee S, Dai H. Chemically Derived, Ultrasmooth Graphene Nanoribbon Semiconductors. Science. 2008;319(5867):1229-32.

[38] Chew SY, Ng SH, Wang JZ, Novak P, Krumeich F, Chou SL, et al. Flexible freestanding carbon nanotube films for model lithium-ion batteries. Carbon. 2009;47(13):297683. 
[39] Kaiser MR, Liang X, Konstantinov K, Liu H-K, Dou S-X, Wang J-Z. A Facile Synthesis of High-Surface-Area Sulfur-Carbon Composite for Li/S Batteries. Chemistry - A European Journal. 2015:n/a-n/a.

[40] Bahloul B, Amirouche L, Dekhira A, Bentabet A. Ab initio study of the structural, electronic and elastic properties of anti-fluorite $\mathrm{Li} 2 \mathrm{X}$ (X\&\#xa0;=\&\#xa0;S and $\mathrm{Te}$ ) compounds under pressure effect. Computational Materials Science. 2014;86(0):49-56.

[41] Nagao M, Hayashi A, Tatsumisago M. High-capacity Li2S-nanocarbon composite electrode for all-solid-state rechargeable lithium batteries. J Mater Chem. 2012;22(19):10015-20.

[42] Zhao Q, Hu X, Zhang K, Zhang N, Hu Y, Chen J. Sulfur Nanodots Electrodeposited on Ni Foam as High-Performance Cathode for Li-S Batteries. Nano Lett. 2015;15(1):721-6.

[43] Sa Q, Wang Y. Ni foam as the current collector for high capacity C-Si composite electrode. J Power Sources. 2012;208(0):46-51.

[44] Meini S, Elazari R, Rosenman A, Garsuch A, Aurbach D. The Use of Redox Mediators for Enhancing Utilization of Li2S Cathodes for Advanced Li-S Battery Systems. J Phys Chem Lett. 2014;5(5):915-8.

[45] Goodenough JB, Park K-S. The Li-Ion Rechargeable Battery: A Perspective. J Am Chem Soc. 2013;135(4):1167-76.

[46] Seh ZW, Wang HT, Hsu PC, Zhang QF, Li WY, Zheng GY, et al. Facile synthesis ofLi2S-polypyrrole composite structures for high-performance Li2S cathodes. Energ Environ Sci. 2014;7(2):672-6.

[47] Su YS, Manthiram A. A new approach to improve cycle performance of rechargeable lithium-sulfur batteries by inserting a free-standing MWCNT interlayer. Chem Commun. 2012;48(70):8817-9. 
[48] Wang XF, Wang ZX, Chen LQ. Reduced graphene oxide film as a shuttle-inhibiting interlayer in a lithium-sulfur battery. J Power Sources. 2013;242:65-9.

[49] Jeong T-G, Moon YH, Chun H-H, Kim HS, Cho BW, Kim Y-T. Free standing acetylene black mesh to capture dissolved polysulfide in lithium sulfur batteries. Chem Commun. 2013;49(94):11107-9.

Figures

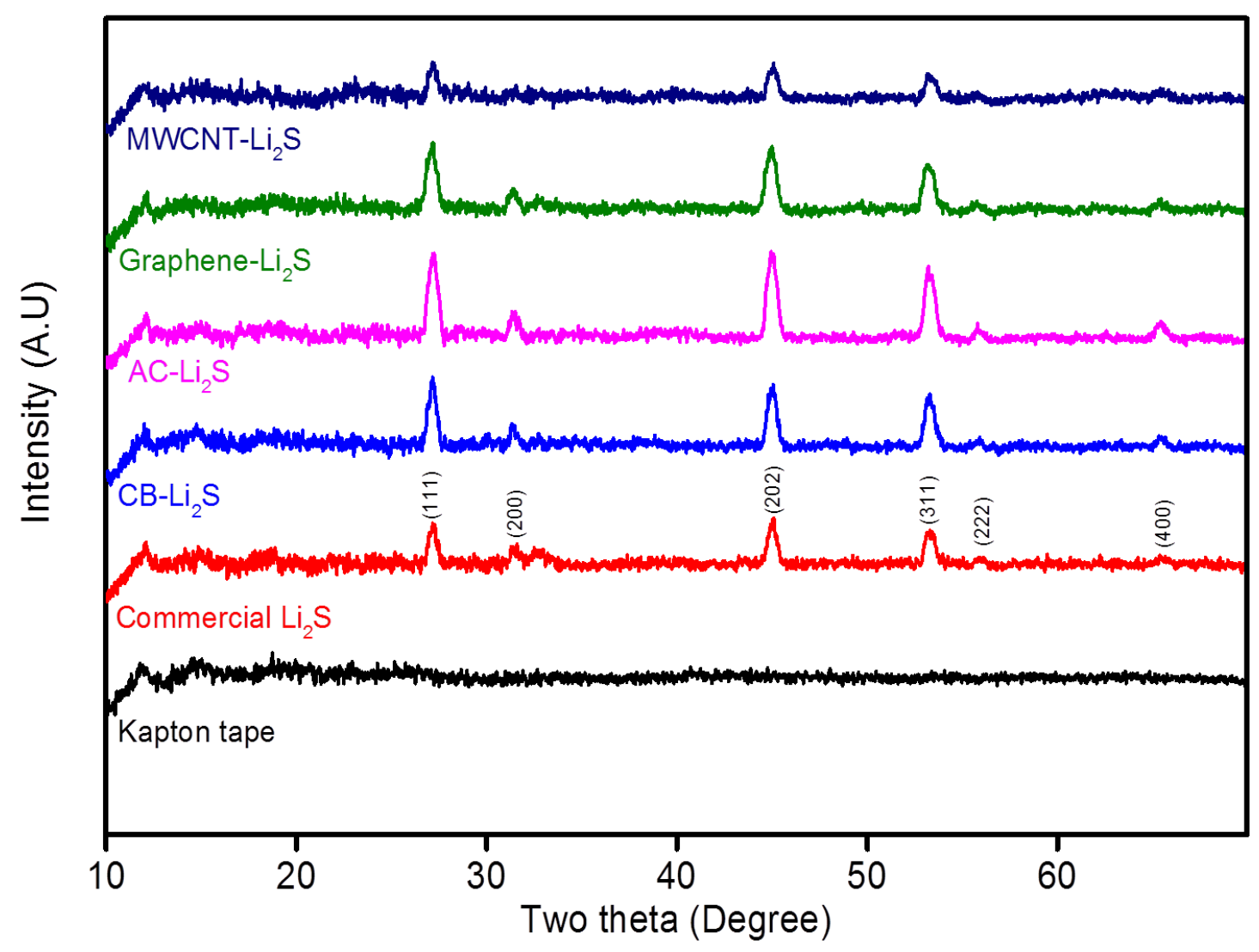

Figure 1: XRD patterns of $\mathrm{Li}_{2} \mathrm{~S}-\mathrm{C}$ composites. 


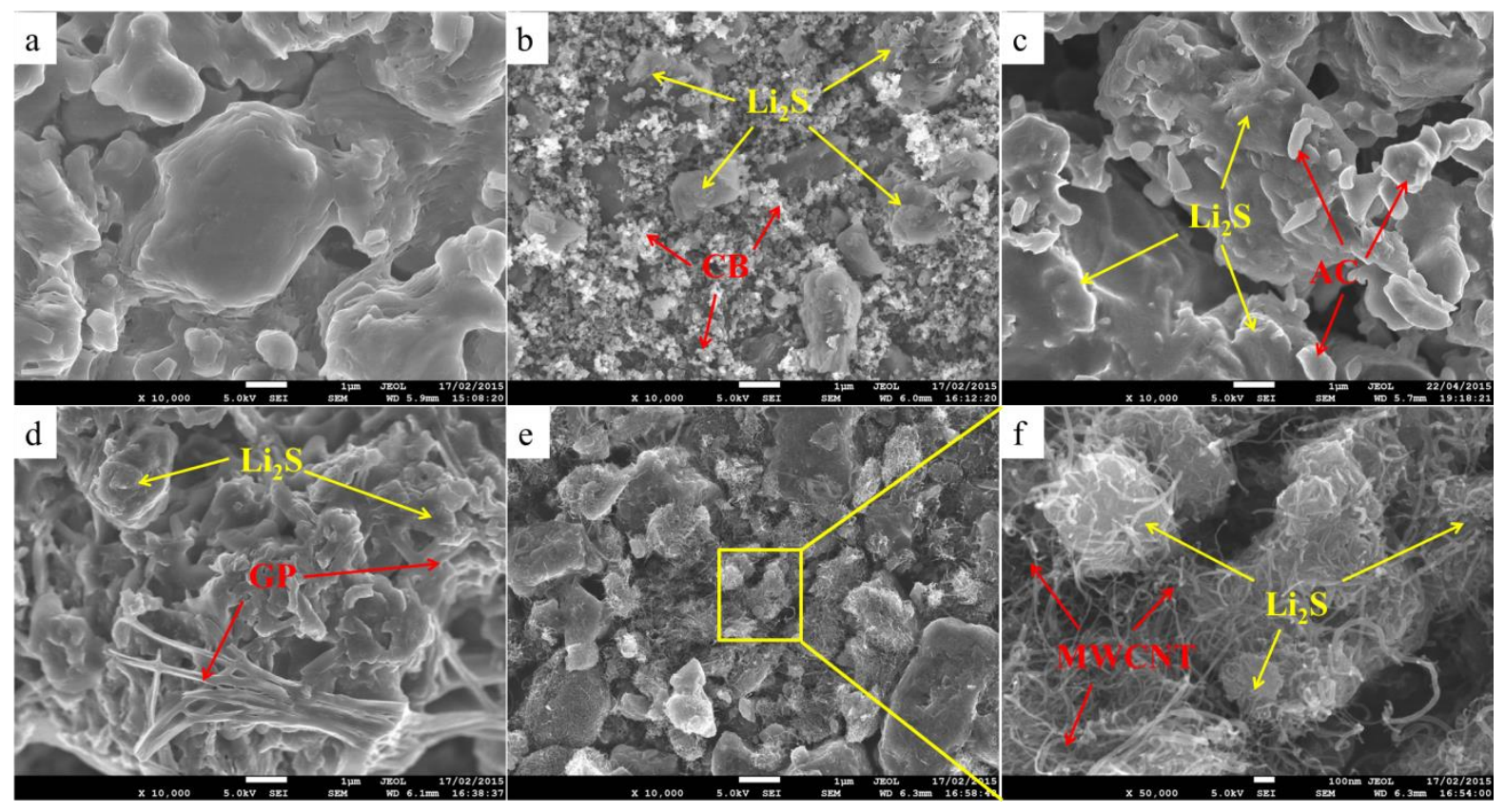

Figure 2: FESEM images of a) $\mathrm{Li}_{2} \mathrm{~S}$, b) $\mathrm{Li}_{2} \mathrm{~S}-\mathrm{CB}$, c) $\mathrm{Li}_{2} \mathrm{~S}-\mathrm{AC}$, d) $\mathrm{Li}_{2} \mathrm{~S}-\mathrm{GP}$, and e, f) $\mathrm{Li}_{2} \mathrm{~S}-$ MWCNT composites (Scale bars are $1 \mu \mathrm{m}$ for Figures-a, b, c, d, e and $100 \mathrm{~nm}$ for Figure-f). 


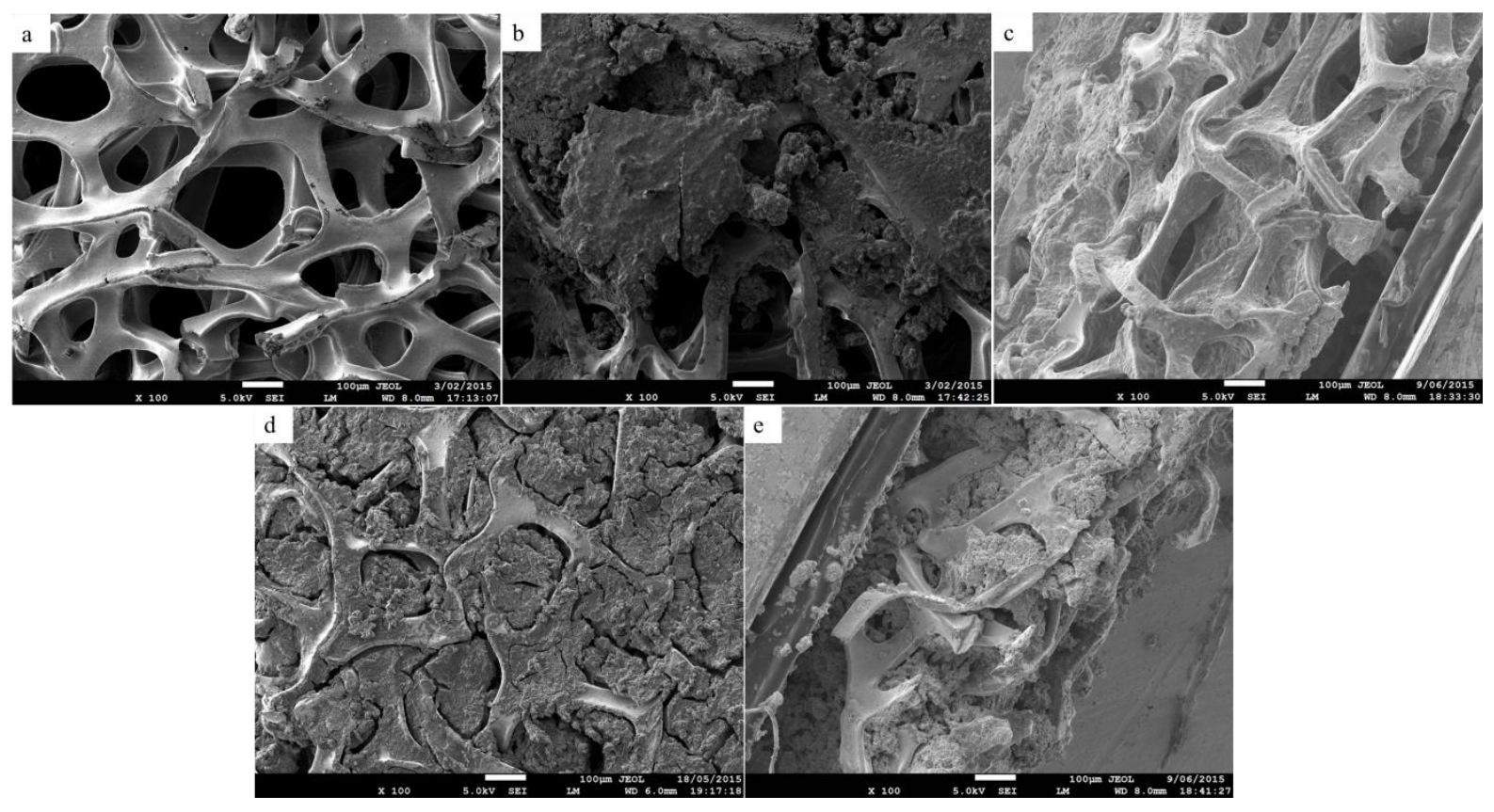

Figure 3: FESEM image of a) Ni-foam, and b, c) top view and side view images of $\mathrm{Li}_{2} \mathrm{~S}$ MWCNT composite cathode, where the active material was loaded in Ni-foam through powder dispersion; d, e) top view and side view images of $\mathrm{Li}_{2} \mathrm{~S}-\mathrm{MWCNT}$ composite cathode where the active material was loaded in Ni-foam through capillary deposition (Scale bars for all the figures are $100 \mu \mathrm{m})$. 

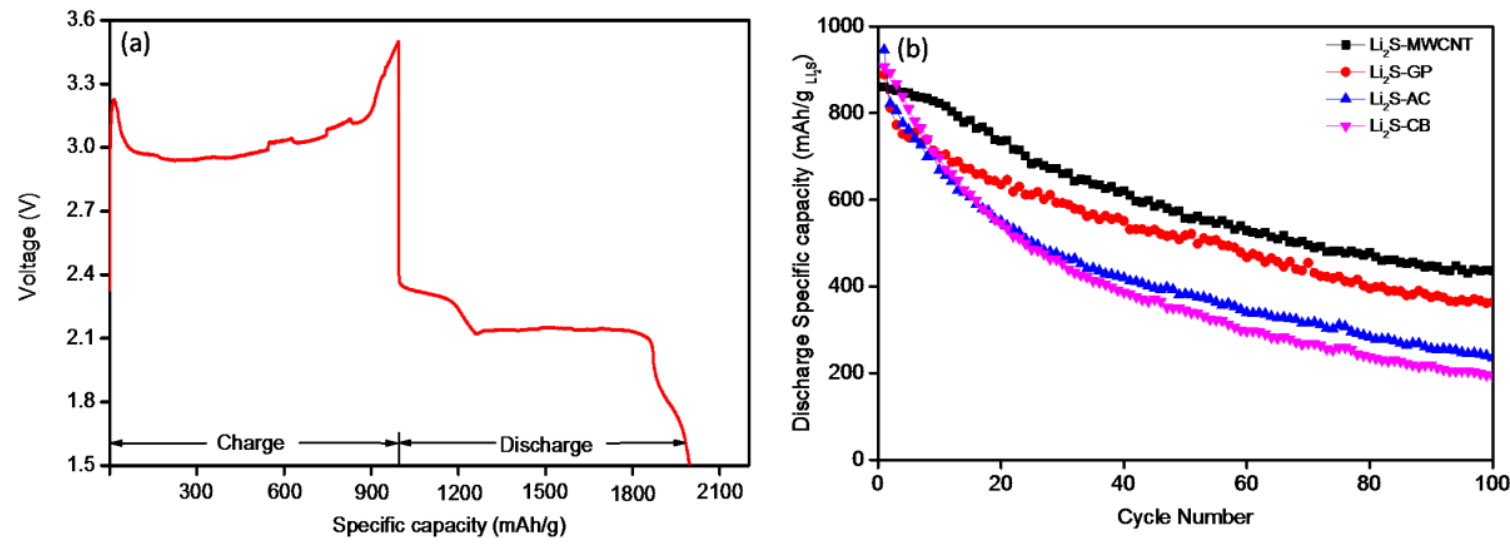

Figure 4: (a) Charge discharge profile of first cycle for activation of $\mathrm{Li}_{2} \mathrm{~S}-\mathrm{MWCNT}$ composite (b) Cycling performance of $\mathrm{Li}_{2} \mathrm{~S}-\mathrm{C}$ composites at the $0.1 \mathrm{C}$ rate. 

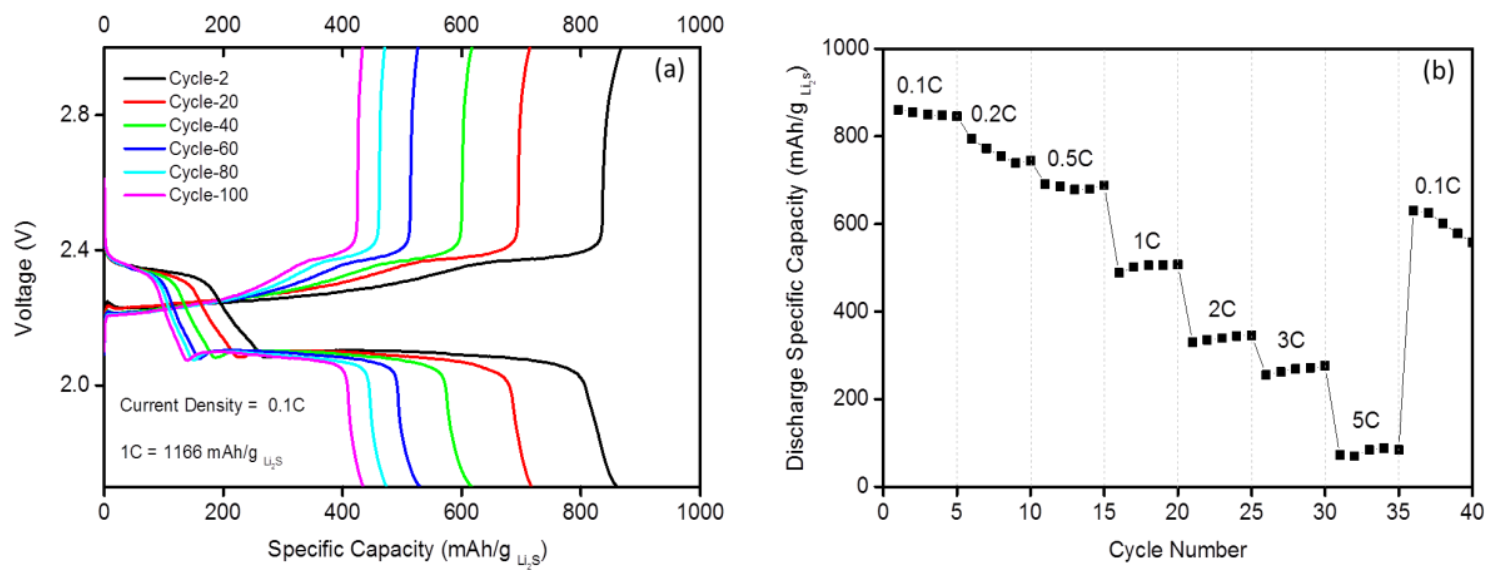

Figure 5: (a) Charge-discharge profiles, and (b) rate capability of $\mathrm{Li}_{2} \mathrm{~S}-\mathrm{MWCNT}$ composite. 

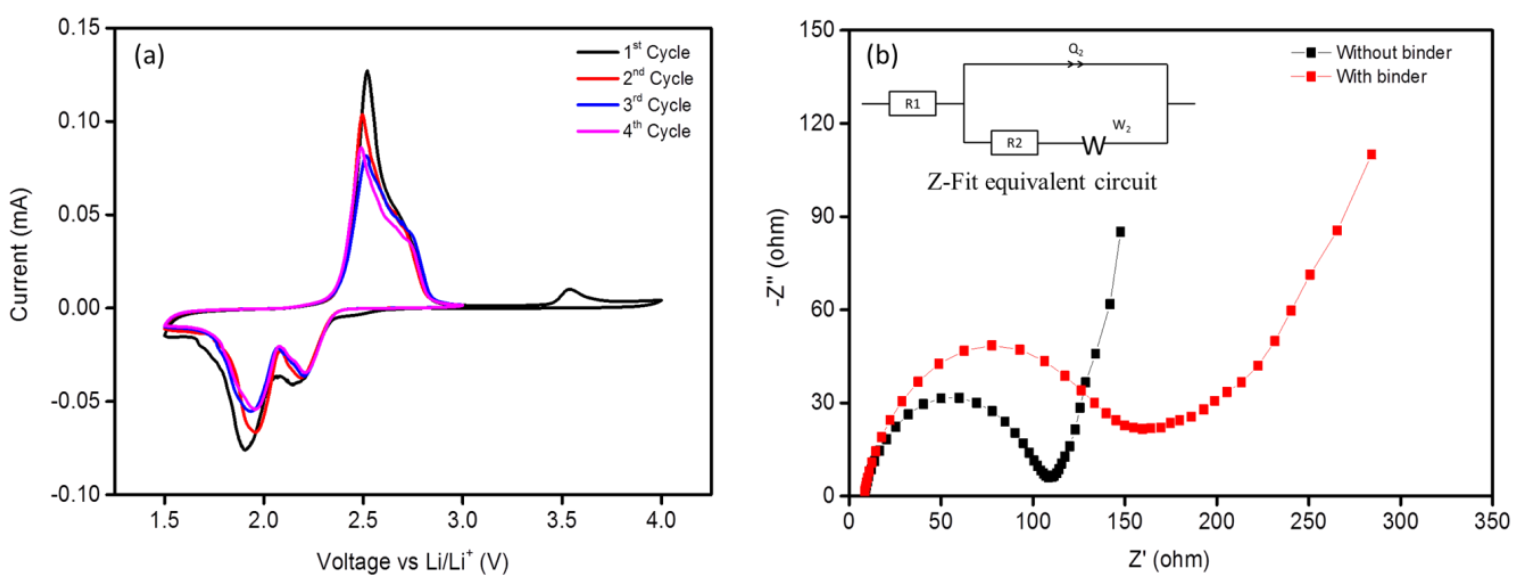

Figure 6: a) Cyclic voltammetry (CV) curves for the first 4 cycles and b) electrochemical impedance spectra (EIS) of $\mathrm{Li}_{2} \mathrm{~S}-\mathrm{MWCNT}$ composite. The inset to the EIS spectra is the ZFit equivalent circuit. 


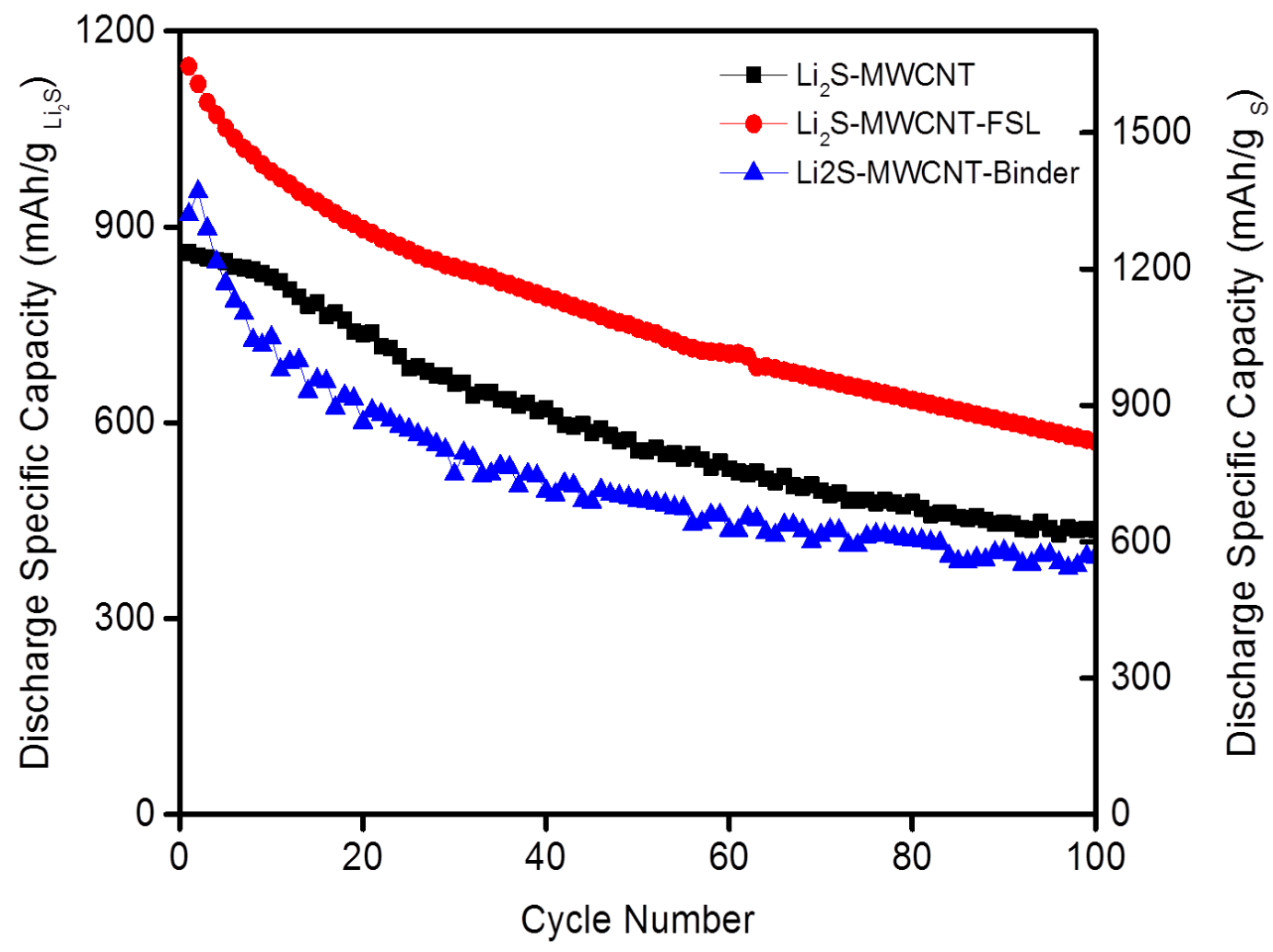

Figure 7: Cycling performance at the $0.1 \mathrm{C}$ rate of $\mathrm{Li}_{2} \mathrm{~S}-\mathrm{MWCNT}$ composite with binder and FSL.

\section{Supporting Information}

\section{A Methodical approach for Fabrication of Binder-free $\mathrm{Li}_{2} \mathrm{~S}-\mathrm{C}$ composite Cathode with High Loading of Active Material for Li-S Battery}

Mohammad Rejaul Kaiser,Xin Liang, Hua-Kun Liu, Shi-Xue Dou, and JiazhaoWang ${ }^{a, *}$

${ }^{a}$ Institute for Superconducting and Electronic Materials, University of Wollongong, Wollongong, NSW 2522, Australia

*Correspondence address:jiazhao@uow.edu.au 


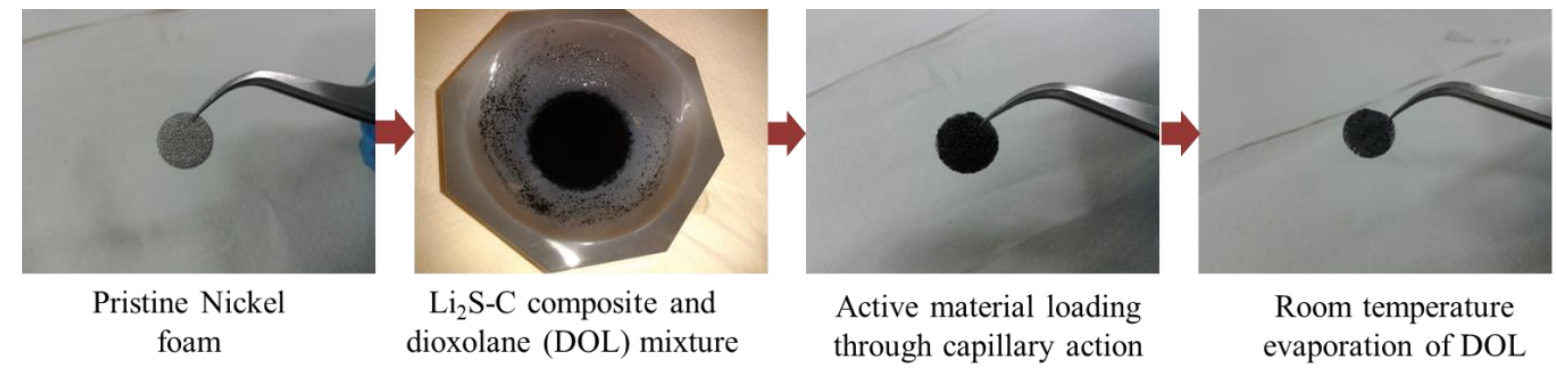

Figure S1: Encapsulation of active materials in 3-D Ni foam.

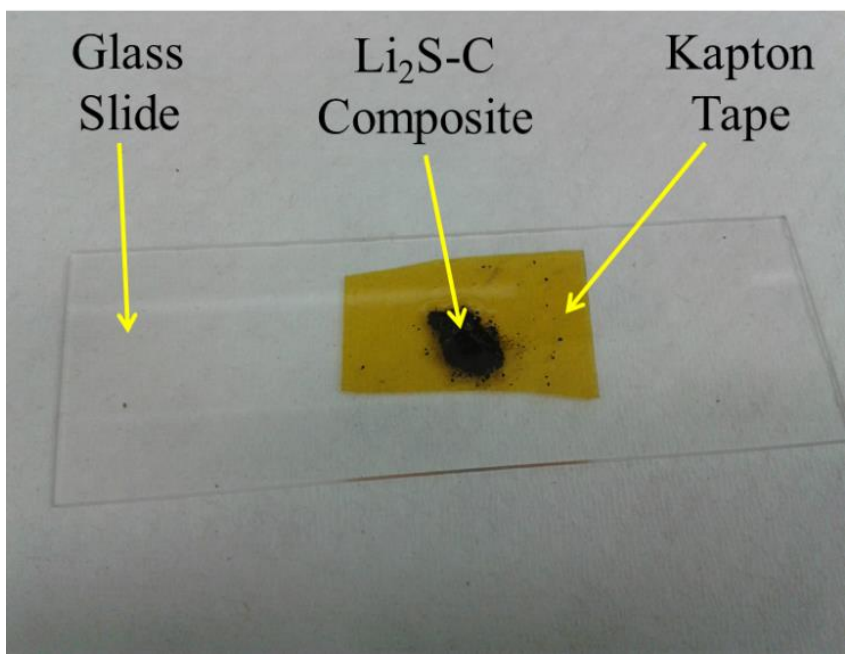

Figure S2: Sample prepared for XRD analysis. 


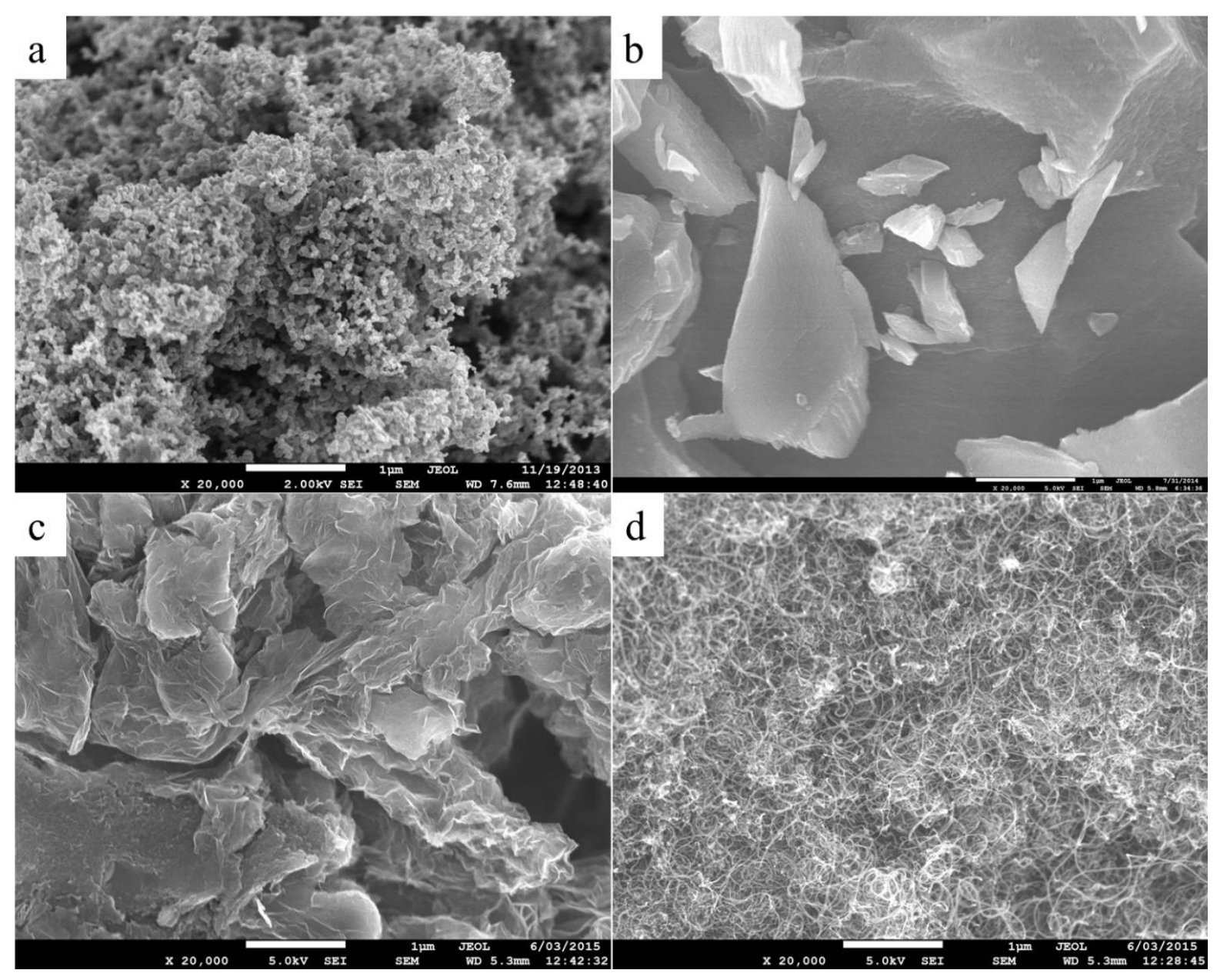

Figure S3: FESEM images of a) carbon black (CB), b) activated carbon (AC), c) graphene (GP), and d) multi-walled carbon nanotube (MWCNT) ( Scale bars for all the figures are 1 $\mu \mathrm{m})$. 


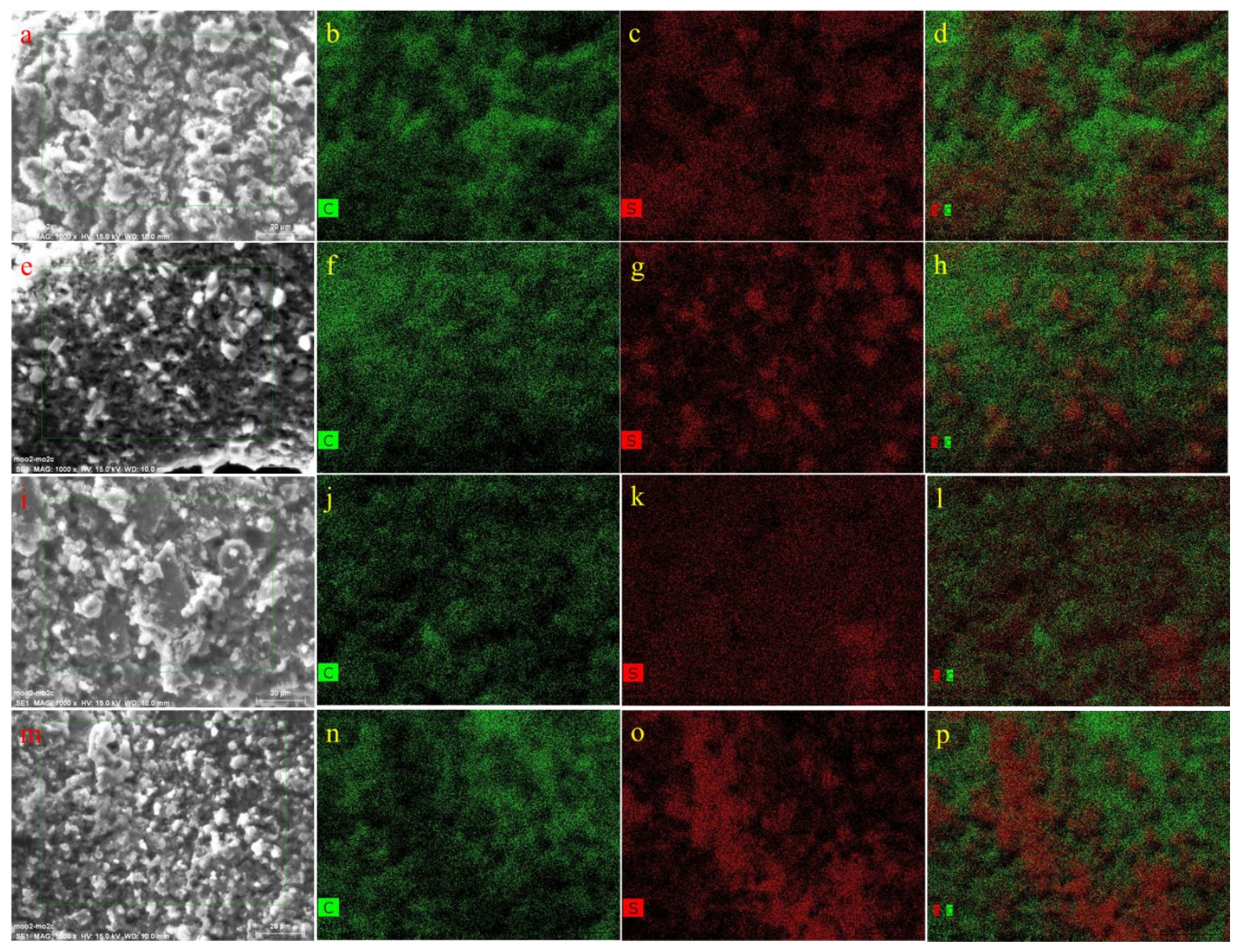

Figure S4: EDS mapping of a-d) $\mathrm{Li}_{2} \mathrm{~S}-\mathrm{CB}$, e-h) $\mathrm{Li}_{2} \mathrm{~S}-\mathrm{AC}$, i-l) $\mathrm{Li}_{2} \mathrm{~S}-\mathrm{GP}$, and m-p) $\mathrm{Li}_{2} \mathrm{~S}-$ MWCNT (Scale bars for all the figures are $20 \mu \mathrm{m}$ ). 


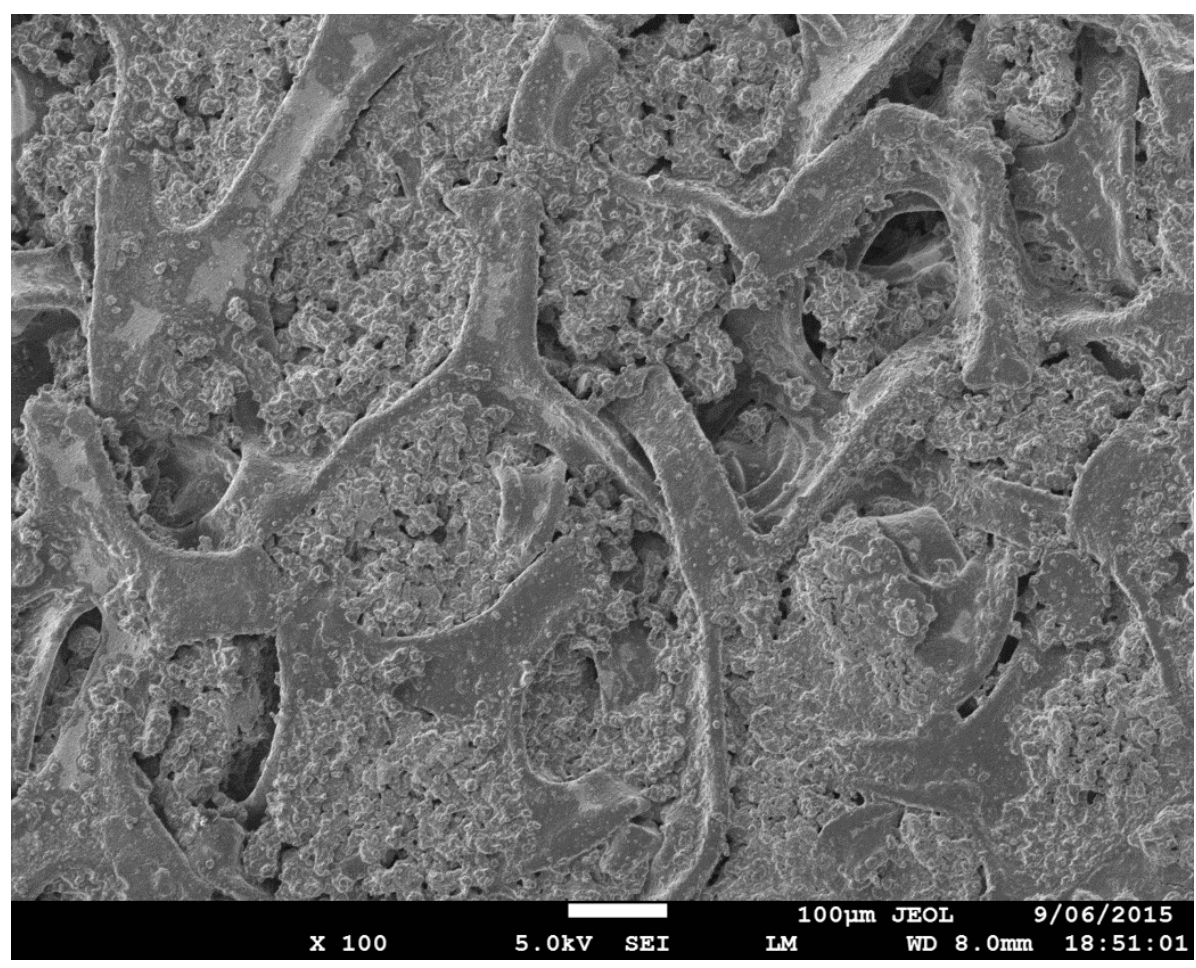

Figure S5: FESEM image of $\mathrm{Li}_{2} \mathrm{~S}-\mathrm{MWCNT}$ composite confined in Ni-foam after cycling.

Table 1: Comparison of properties and performance of $\mathrm{Li}_{2} \mathrm{~S}-\mathrm{C}$ composites for $\mathrm{Li} / \mathrm{S}$ battery.

\begin{tabular}{|c|c|c|c|c|c|}
\hline $\begin{array}{c}\text { Discharge capacity } \\
\left(\mathbf{m A h} / \mathbf{g} \mathbf{L i}_{2} \mathbf{S}\right)\end{array}$ & $\begin{array}{c}\text { Binder } \\
\mathbf{u s e}\end{array}$ & $\begin{array}{c}\text { Active } \\
\mathbf{m a t e r i a l} \\
(\mathbf{w t} \mathbf{)})\end{array}$ & $\begin{array}{c}\text { Active } \\
\mathbf{m a t e r i a l} \\
\left(\mathbf{m g} / \mathbf{c m}^{2}\right)\end{array}$ & Current collector & Reference \\
\hline 250 after 50 cycles & Yes & 60 & NA & $\begin{array}{c}\text { 2-D Aluminum } \\
\text { foil }\end{array}$ & {$[39]$} \\
\hline 650 after 80 cycles & Yes & NA & 1.0 & $\begin{array}{c}\text { Carbon nano } \\
\text { fiber }\end{array}$ & {$[40]$} \\
\hline 380 after 20 cycles & Yes & 38 & NA & $\begin{array}{c}\text { Copper } \\
\text { composite }\end{array}$ & {$[21]$} \\
\hline 600 after 100 cycles & Yes & 60 & $1.0-1.5$ & $\begin{array}{c}\text { 2-D Carbon } \\
\text { paper }\end{array}$ & {$[25]$} \\
\hline 550 after 400 cycles & Yes & 60 & NA & $\begin{array}{c}\text { 2-D Aluminum } \\
\text { foil }\end{array}$ & {$[41]$} \\
\hline 650 after 150 cycles & Yes & NA & 1.0 & $\begin{array}{c}\text { 2-D Aluminum } \\
\text { foil }\end{array}$ & {$[42]$} \\
\hline 500 after 50 cycles & Yes & 40 & 1.0 & $\begin{array}{c}\text { 2-D carbon } \\
\text { paper }\end{array}$ & {$[23]$} \\
\hline 550 after 150 cycles & Yes & NA & 1.0 & $\begin{array}{c}\text { 2-D Aluminum } \\
\text { foil }\end{array}$ & {$[26]$} \\
\hline 620 after 100 cycles & No & NA & 1.0 & $\begin{array}{c}\text { MWCNT } \\
\text { paper }\end{array}$ & {$[43]$} \\
\hline 300 after 95 cycles & Yes & 55 & 0.96 & $\begin{array}{c}\text { 2-D Aluminum } \\
\text { foil }\end{array}$ & {$[44]$} \\
\hline 320 after 20 cycles & Yes & 49 & $1.1-1.4$ & $\begin{array}{c}\text { 2-D Aluminum } \\
\text { foil }\end{array}$ & {$[45]$} \\
\hline 450 after 150 cycles & No & NA & $0.8-1.5$ & Graphene oxide & {$[28]$} \\
\hline
\end{tabular}




\begin{tabular}{|c|c|c|c|c|c|}
\hline & & & & layer & \\
\hline 437 after 100 cycles & No & 70 & $5.0-6.0$ & $\begin{array}{c}\text { 3-D Nickel } \\
\text { foam }\end{array}$ & This work \\
\hline
\end{tabular}

Table 2: Z-fitted EIS results for $\mathrm{Li}_{2} \mathrm{~S}-\mathrm{MWCNT}$ composite.

\begin{tabular}{|c|c|c|c|c|c|}
\hline & $\begin{array}{c}\text { Impedance } \\
\text { values }\end{array}$ & $\mathrm{R}_{\mathrm{e}}(\Omega)$ & $\mathrm{R}_{\mathrm{ct}}(\Omega)$ & $\mathrm{CPE}(\mu \mathrm{F})$ & $\mathrm{W}\left(\Omega . \mathrm{S}^{-0.5}\right)$ \\
\hline \multirow{2}{*}{$\begin{array}{c}\mathrm{Li}_{2} \mathrm{~S}-\mathrm{MWCNT} \\
\text { composite }\end{array}$} & Without binder & 7.993 & 93.51 & 21.43 & 19.12 \\
\cline { 2 - 6 } & With binder & 7.322 & 154.8 & 21.98 & 45.35 \\
\hline
\end{tabular}

